\title{
Communication \\ Diet in Irritable Bowel Syndrome (IBS): Interaction with Gut Microbiota and Gut Hormones
}

\author{
Magdy El-Salhy ${ }^{1,2,3, *}$, Jan Gunnar Hatlebakk ${ }^{2,3}$ (D) and Trygve Hausken 2,3(1) \\ Section for Gastroenterology, Department of Medicine, Stord Hospital, 5409 Stord, Norway \\ Department of Clinical Medicine, University of Bergen, 5007 Bergen, Norway \\ 3 National Centre for Functional Gastrointestinal Disorders, 5021 Bergen, Norway \\ * Correspondence: magdy.el-salhy@helse-fonna.no; Tel.: +47-5349-1000; Fax: +47-5349-1001
}

Received: 23 July 2019; Accepted: 5 August 2019; Published: 7 August 2019

\begin{abstract}
Diet plays an important role not only in the pathophysiology of irritable bowel syndrome (IBS), but also as a tool that improves symptoms and quality of life. The effects of diet seem to be a result of an interaction with the gut bacteria and the gut endocrine cells. The density of gut endocrine cells is low in IBS patients, and it is believed that this abnormality is the direct cause of the symptoms seen in IBS patients. The low density of gut endocrine cells is probably caused by a low number of stem cells and low differentiation progeny toward endocrine cells. A low fermentable oligo-, di-, monosaccharide, and polyol (FODMAP) diet and fecal microbiota transplantation (FMT) restore the gut endocrine cells to the level of healthy subjects. It has been suggested that our diet acts as a prebiotic that favors the growth of a certain types of bacteria. Diet also acts as a substrate for gut bacteria fermentation, which results in several by-products. These by-products might act on the stem cells in such a way that the gut stem cells decrease, and consequently, endocrine cell numbers decrease. Changing to a low-FODMAP diet or changing the gut bacteria through FMT improves IBS symptoms and restores the density of endocrine cells.
\end{abstract}

Keywords: diet; fecal microbiota transplantation; gut endocrine cells; gut microbiota; IBS

\section{Introduction}

It has been estimated that $12.1 \%$ of the world's population suffers from irritable bowel syndrome (IBS) $[1,2]$. The main symptom of IBS is recurrent abdominal pain associated with a change in the bowel habits according to Rome IV criteria [3]. The diagnosis of IBS is based mainly on an assessment of the symptoms as described by Rome criteria [4]. Based on stool patterns, IBS patients are divided into four subtypes: diarrhea-predominant (IBS-D), constipation-predominant (IBS-C), mixed diarrhea and constipation (IBS-M), and patients who meet the diagnostic criteria for IBS, but whose bowel habits cannot be accurately categorized (IBS-U) $[5,6]$.

IBS is usually diagnosed in young patients in a phase of their lives when they are trying to build a family and getting an education/working [7-18]. IBS reduces the patient's quality of life to the same degree as other chronic diseases such as diabetes, inflammatory bowel diseases, and kidney failure [18-21]. IBS patients generate a substantial workload in both primary and secondary care, and $12-14 \%$ of primary care patient visits and $28 \%$ of referrals to gastroenterologists are IBS patients $[12,13,22]$. Thus, IBS is a more common reason for a visit to a physician than diabetes, hypertension, or asthma [23,24].

IBS patients can be divided into two subsets: sporadic (nonspecific) and post-infectious (PI) [19]. Sporadic IBS includes patients who have had symptoms for a long time without any associated events. PI-IBS occurs in otherwise healthy subjects as a sudden onset of IBS symptoms after gastroenteritis [19]. PI-IBS comprises about $6-17 \%$ of patients with IBS [25]. 
There is no effective treatment for IBS, and the treatment practiced in the clinic is directed toward the relief of symptoms [26]. An international survey showed that these patients would give up 25\% of their remaining life (average 15 years) and 14\% would risk a 1/1000 chance of death to receive a treatment that would make them symptom-free [27].

The etiology of IBS is not completely understood, but several factors are believed to play a pivotal role in the pathophysiology of IBS. These factors are genetics, diet, gut microbiota, gut endocrine cells, and low-grade inflammation [1]. Studies of family history and family cluster, as well as twin studies, provide strong evidence that IBS is hereditary [28-35]. However, the gene responsible for IBS has not been determined yet $[1,36]$. Low-grade inflammation occurs in some IBS patients, but far from all [1]. Diet, gut microbiota, and gut endocrine cells interact with each other in a way that affect IBS symptoms. The present review is an attempt to clarify this interaction and the possible implications for everyday clinical work.

\section{Diet in IBS}

Patients with IBS attribute their symptoms to specific food items such as milk and milk products, wheat products, cabbage, onion, peas/beans, hot spices, and fried food [37-41]. Despite the selective choice of food by IBS patients, the intake of calories, carbohydrates, proteins, and fats by IBS patients is similar to community controls $[38,42,43]$. There was no difference either in the number of meals or meal patterns between IBS patients and community controls [38]. However, the diets of IBS patients are lower in $\beta$-carotene, retinol, riboflavin, calcium, magnesium, and phosphorous [38]. Moreover, IBS patients avoid certain food items, some of which belong to the fermentable oligo-, di-, monosaccharides, and polyols (FODMAPs) group, but they have a high consumption of other food items that are rich in FODMAPs [38]. They also consume more food with probiotic supplements and avoid fewer food sources that are important to their health [38].

The influence of diet on IBS symptoms was previously explained by food allergy/intolerance, and poorly absorbed carbohydrates and fiber [44]. There is no evidence that food allergy/intolerance is involved in IBS, but it is generally accepted that poorly absorbed carbohydrates and fiber play an important role in the development of IBS symptoms [44,45]. The intake of a low FODMAP-diet improves both symptoms and quality of life in IBS patients (Table 1) $[37,44,46,47]$. However, only $50-70 \%$ of IBS patients have effect of low FODMAP-diet [48-50]. Moreover, a low FODMAP-diet is expensive and hard to maintain over a long time and changes the intestinal microbiota negatively [49,51-53]. Furthermore, the intake of low FODMAP-diet over a long time may cause deficiencies in vitamins, minerals, and naturally occurring antioxidants [52,53]. A NICE (National Institute for Health and Care Excellence)-modified diet (Table 2) has the same effect as a low FODMAP-diet, is easy to maintain, and does not have the hazards seen with the FODMAP-reduced diet [49,50]. The NICE-modified diet is now the diet first recommended to patients with IBS [54,55]. In our clinic, we use a slightly modified NICE diet, as recommended by the British Dietetic Association [37,38]. In this diet, the patients are asked to have regular meals, to replace wheat products with spelt products, to reduce their intake of fatty food, onions, cabbage, and beans, to avoid soft drinks and carbonated beverages, chewing gum, and sweeteners that end with -ol, and to regularly intake of psyllium husk fibers. The British Dietetic Association also recommends reducing coffee drinking, and avoiding spicy foods and alcohol $[37,38]$. However, these three food items' association to IBS needs more clarification.

Caffeine is not known to affect IBS symptoms. However, a large number of IBS patients suffer from reflux esophagitis [4], and reducing their coffee intake would improve their reflux symptoms. 
Table 1. Food items rich in fermentable oligo-, di-, monosaccharides, and polyols (FODMAPs).

\begin{tabular}{lll}
\hline \multicolumn{1}{c}{ Vegetables } & \multicolumn{1}{c}{ Fruits } & \multicolumn{1}{c}{ Others } \\
\hline & & $\begin{array}{l}\text { Wheat, barley, rye, bread, pasta, } \\
\text { Couscous, biscuits, cakes }\end{array}$ \\
\cline { 2 - 2 } $\begin{array}{l}\text { Onions, garlic, the white } \\
\text { portion of leeks and spring } \\
\text { onions, cabbage, spring onions, } \\
\text { mushrooms, beans, red kidney } \\
\text { beans, Brussels sprouts, sugar } \\
\text { peas, asparagus, lentils, beets, } \\
\text { artichoke, fennel, peas, sugar } \\
\text { peas, cauliflower }\end{array}$ & $\begin{array}{l}\text { Apples, pears, peach, mango, } \\
\text { canned fruit in natural juice, } \\
\text { nashiphary, apricot, longan, cherry, } \\
\text { lychee, nectarine, plum }\end{array}$ & $\begin{array}{l}\text { Milk and dairy products: cheese, } \\
\text { yogurt, soy milk, cream }\end{array}$ \\
\cline { 2 - 3 } & & $\begin{array}{l}\text { Sweeteners containing fructose (for } \\
\text { example, corn syrup) }\end{array}$ \\
\cline { 2 - 3 } & & $\begin{array}{l}\text { Sweeteners: sorbitol, mannitol, xylitol, } \\
\text { isomalt, maltitol, and other } \\
\text { sweeteners with names ending in "ol" }\end{array}$ \\
\hline
\end{tabular}

Table 2. The food items that should be avoided in a National Institute for Health and Care Excellence (NICE)-modified diet.

\begin{tabular}{|c|c|c|}
\hline Vegetables & Fruits & Others \\
\hline $\begin{array}{l}\text { Onions, garlic, beans, } \\
\text { peas, artichoke, cabbage }\end{array}$ & Watermelon & $\begin{array}{l}\text { Wheat flour and wheat-based products } \\
\text { Milk and dairy products } \\
\text { Sweeteners containing fructose (for example, corn syrup) } \\
\text { Sweeteners: sorbitol, menthol, xylitol, isomalt, maltitol, and } \\
\text { other sweeteners with names ending in "ol" } \\
\text { Carbonated drinks (soft drinks), coffee, beer }\end{array}$ \\
\hline
\end{tabular}

IBS patients are known to consume less alcohol than the normal population, and $12 \%$ of them avoid alcoholic beverages [38,56-58]. Chronic alcohol consumption affects gastrointestinal motility, damages the gut mucosal, impairs nutrient absorption, and causes inflammation [59-64]. The mechanism by which alcohol affects gastrointestinal motility is thought to be by inhibiting nitric oxide pathways [59-63]. Whereas the previously mentioned effects of alcohol on the gastrointestinal tract have been detected in chronic alcohol abuse, the effects of moderate social consumption of alcohol on gastrointestinal tract functions are not known.

Whereas some studies have shown that drinking alcoholic beverages induces symptoms in IBS patients [56,65,66], others have not [67]. These contradictory results could be explained by the observation that moderate and light drinking are not associated with IBS symptoms, but binge drinking is [68]. Moreover, there is marked individual variation in alcohol drinking being a trigger of IBS symptoms [68]. The recommendation of the British Dietetic Association is that each individual should assess the relation between alcohol intake and symptom developments in order to determine whether a reduction is necessary. This recommendation works well in the clinical setting.

Capsaicin is the major component in spicy food with hot peppers. Capsaicin accelerates gastrointestinal transit through TRPV receptors, hence causing abdominal pain [69]. Several studies have shown that spicy food induces the onset of IBS symptoms $[56,65-67,70]$. It has been shown, however, that whereas an occasional ingestion of chili increases abdominal pain/discomfort [70,71], chronic intake of chili decreases abdominal pain and bloating in IBS patients [72,73]. This effect seems to be caused by desensitization effects of capsaicin ingestion on TRPV1 receptors [74]. Asians consume 2.5-8g/person of chili daily, which is 10-300 times higher than the intake of Europeans [75-77]. This probably can explain why Asian patients with IBS have less abdominal pain and the alteration in bowel habits is much less prominent in Asian IBS patients than in Western patients [78-81].

\section{Gut Microbiota}

It has been estimated that more than $10^{14}$ microorganisms are harbored in the human gut [82]. The gut is inhabited by 12 different bacteria phyla, comprising 2172 species. Most gut bacteria belongs to the Proteobacteria, Firmicutes, Actinobacteria, and Bacteroidetes phyla [83]. However, anaerobic 
Firmicutes and Bacteroidetes dominate the bacterial population in the gut of healthy adults, with a few members from of the Proteobacteria and Actinobacteria phyla $[83,84]$. A low microbial diversity in the gut (dysbiosis) is associated with several diseases [85,86].

Bacterial composition in healthy subjects is determined by genetics and environmental factors $[82,86]$. Genetics explains only $5-10 \%$ of the bacterial variability between individuals, which emphasizes the importance of environmental factors [86]. Among these environmental factors are diet, the frequency of antibiotic treatment, treatment with certain non-antibiotic drugs, geographical location, surgery, smoking, and depression [82,86,87].

The gut bacterial composition in IBS patients differs from that of healthy subjects [86,88-90]. IBS patients have a lower abundance of Erysipelotrichaceae and Ruminococcaceae, butyrate-producing bacteria, than healthy controls. Whereas Methanobacterialles, methane-producing bacteria, are more abundant in IBS-C, they are less abundant in IBS-D than in healthy individuals [91,92]. Moreover, IBS patients have been found to exhibit an increase in the abundance of bacteria belonging to Proteobacteria, Veillonella, and Firmicutes, such as Lactobacillus and Ruminococcus, and a decrease in the abundance of Bifidobacterium, Faecalibacterium, Erysipelotrichaceae, and methanogens, as compared with healthy individuals in the community [91,92]. Furthermore, IBS patients have a lower diversity of gut bacteria (dysbiosis) than healthy subjects [86,88-93]. Patients with IBS who did not respond to low-FODMAP or NICE-modified diets have been found to suffer from a severe dysbiosis [58].

Changes in the intestinal microbiota in experimental animals causes gastrointestinal dysmotility, visceral hypersensitivity, altered intestinal permeability, and altered behavior [93]. All of these abnormalities are similar to those encountered in IBS. There is a growing body of evidence showing that intestinal microbiota not only explain the abdominal symptoms of IBS, but also the psychiatric co-morbidity occurring in a considerable number of IBS patients [93]. Although altered gastrointestinal microbiota and dysbiosis in patients with IBS are documented, the microbial signature characterizing these patients is not known yet [93].

\section{Gut Hormones}

There are at least 14 different gut hormones secreted by endocrine cells scattered between the epithelial cells facing the gut lumen [19,94] (Figure 1). These cells are localized to the stomach and the small and large intestine [19]. The different types of gut endocrine cells, their functions, and modes of action have been described in details previously [3,37,94-109]. These cells have specialized microvilli that project into the lumen and function as sensors for the gut contents (mostly for nutrients), and respond to luminal stimuli by releasing their hormones into the lamina propria (Figure 2) [110-122]. Different gut hormones are released from the gut endocrine cells depending on the gut intraluminal contents and the proportions of carbohydrates, proteins, and fats $[19,94]$. Thus, carbohydrate-rich luminal contents stimulate the release of gastric inhibitory peptide (GIP) and enteroglucagon, protein-rich luminal contents cause the release of peptide YY (PYY), pancreatic polypeptide (PP), neuropeptide Y (NPY), motilin, ghrelin, and cholecystokinin (CCK), and fat-rich luminal contents result in the release of neurotensin, enteroglucagon, galanin, motilin, ghrelin, and CCK. These hormones act locally on nearby structures (paracrine mode of action) or by entering the circulating blood and reaching distant targets (endocrine mode of action) [123]. These hormones interact and integrate with each other, with the enteric nervous system, the autonomic nervous system, and the central nervous system $[3,94,98,124]$. Gut hormones regulate several functions of the gastrointestinal tract, including visceral sensation, motility, secretion, absorption, local immune defense, cell proliferation, and food intake $[3,96,108,109,124]$. 


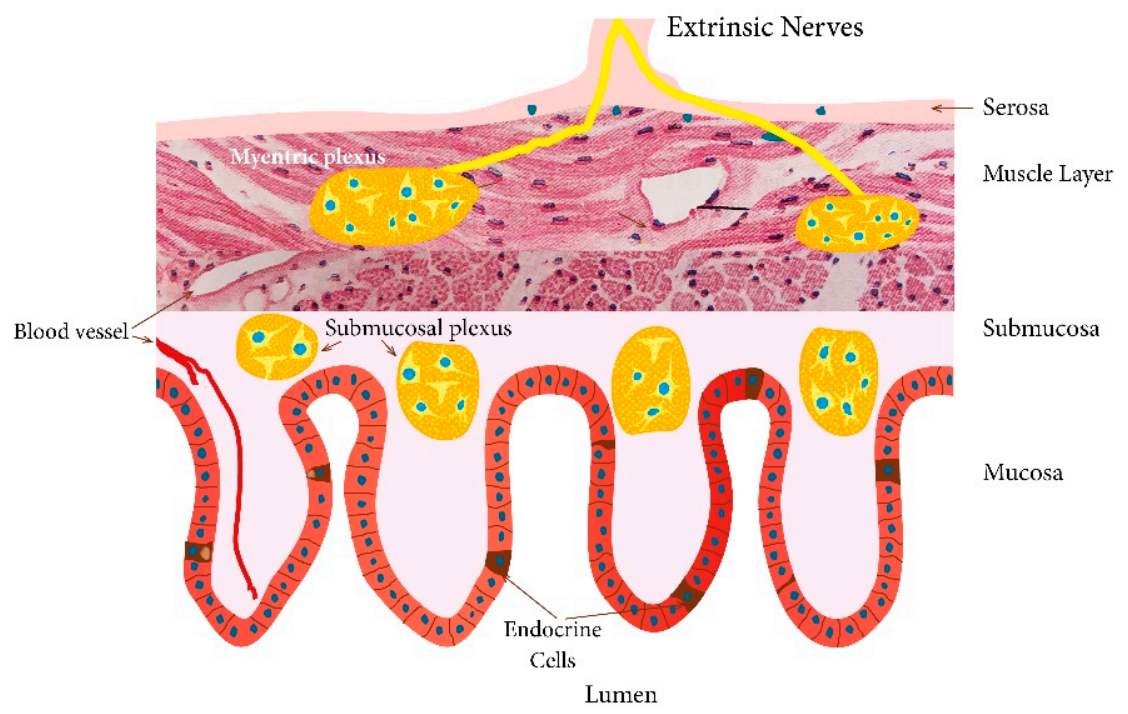

Figure 1. Schematic illustration of the gut endocrine cells. The endocrine cells are scattered among the epithelial cells of the mucosa facing the gut lumen. These cells secret at least 14 different hormones that regulate gut motility, secretion, absorption, visceral sensitivity, local immune defense, cell proliferation, and appetite. These hormones also interact and integrate with the enteric, autonomic, and central nervous systems.

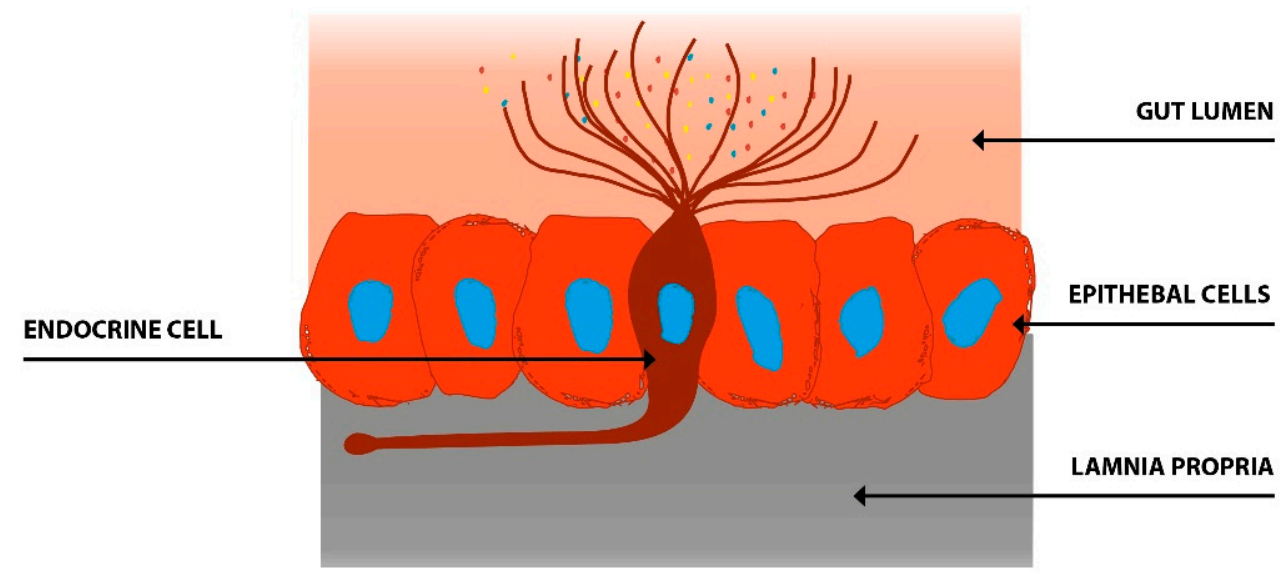

Figure 2. The gut endocrine cells have specialized microvilli that project into the gut lumen and act as sensors for the gut contents (mostly for nutrients). They respond to luminal content by releasing their hormones into the lamina propria. These hormones act locally on nearby structures (paracrine mode of action) or enter the blood stream and act on more distant structures (endocrine mode of action).

Several abnormalities in different endocrine cell types of the stomach and the small and large intestine have been described in IBS patients (Figure 3) [125-136]. Generally, IBS patients have a lower gut endocrine cell density than healthy subjects [94]. A low density of gut endocrine cells occurs in patients with congenital malabsorptive diarrhea, in small intestine allograft rejection, and in NEUROG3-knockout mice [137-139]. The low density of gut endocrine cells in these conditions is accompanied by a reduction in the number of gut neurogenin 3 cells. [137-139]. Neurogenin 3 is a marker for early intestinal endocrine cell progenitors originating from stem cells, which are located at the base of the crypts [138,140-145]. In the small and large intestines of patients with IBS, the cell density of Musashi 1 and neurogenin 3 are lower than that of healthy subjects (Figure 4) [135,146-148]. Musashi 1 is a marker for intestinal stem cells and their early progeny [138,140-145]. 

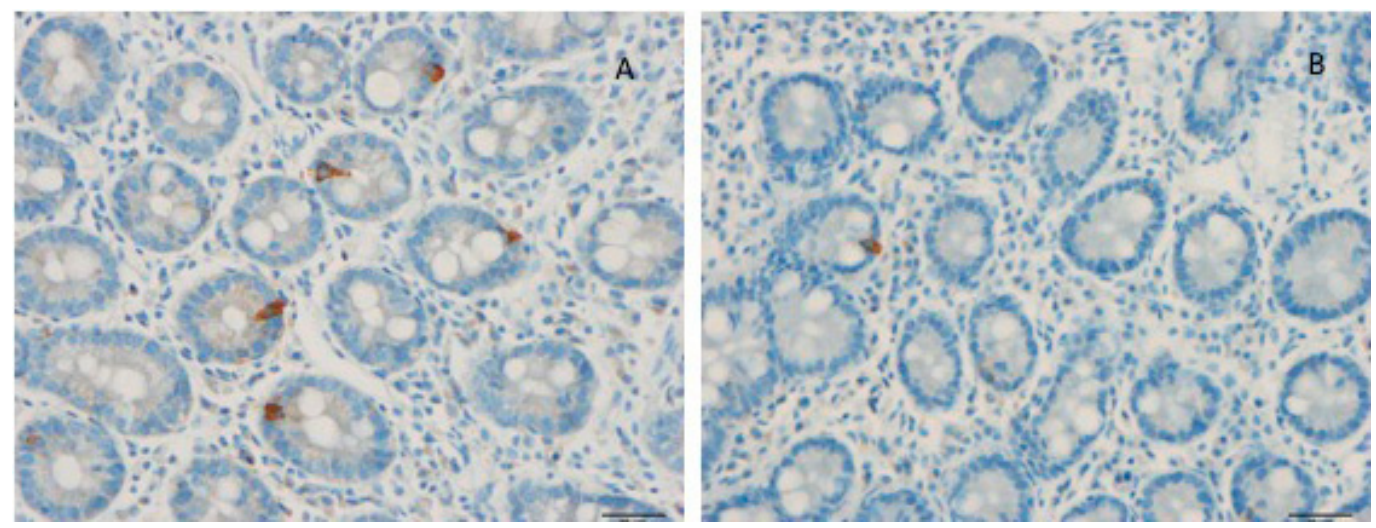

Figure 3. Duodenal cholecystokinin (CCK) cells of a healthy subject (A) and of a patient with irritable bowel syndrome (IBS) (B). Patients with IBS have a low density of CCK cells.
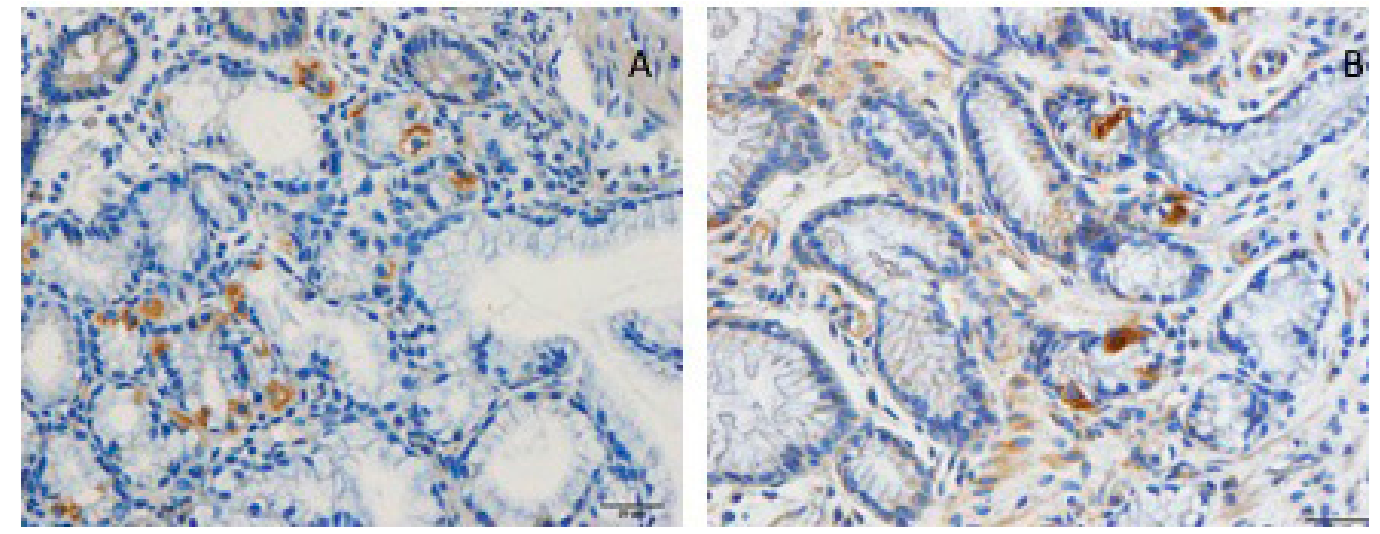

Figure 4. Musashi 1 cells in the duodenum of a healthy subject (A) and in the duodenum of a patient with IBS (B). Musashi 1 is a marker for stem cells and their early progenitors.

Accordingly, it is probable that a low number of these in the stem cells and enteroendocrine cells progenitors might be responsible for the low density of gut endocrine cells [149].

\section{Interaction between Diet, Microbiota, and Endocrine Cells in the Guts of Patients with IBS}

The food that we ingest acts as a substrate (prebiotics) for intestinal bacteria. Our choice of different food items determines our intestinal bacterial profile. On the other hand, intestinal bacteria ferment the undigested remains of the food items into methane and hydrogen gases, as well as short chain fatty acids [92] (Figure 5). Fructans and galactans are substrates for several bacteria and a low-FODMAP diet appears to induce unfavorable changes in the intestinal bacterial profile of IBS patients $[150,151]$. Patients with IBS adhering to a low-FODMAP diet develop a lower abundance of fecal Bifidobacteria as compared with healthy subjects/before intervention [150,151]. Moreover, the absolute and relative numbers of butyrate-producing bacteria have been reported to be reduced following a low-FODMAP diet intervention [150,151].

Patients with IBS have gut dysmotility, visceral hypersensitivity, and abnormal secretion [146]. The hormones secreted from gut endocrine cells regulate gut motility, visceral sensitivity, and secretion [39]. The abnormalities in the gut endocrine cells seem to explain the gut dysmotility, visceral hypersensitivity, and abnormal secretion seen in IBS patients [148]. It is believed that the abnormalities in the gut hormones play a major role in the pathophysiology of IBS $[148,149]$. 


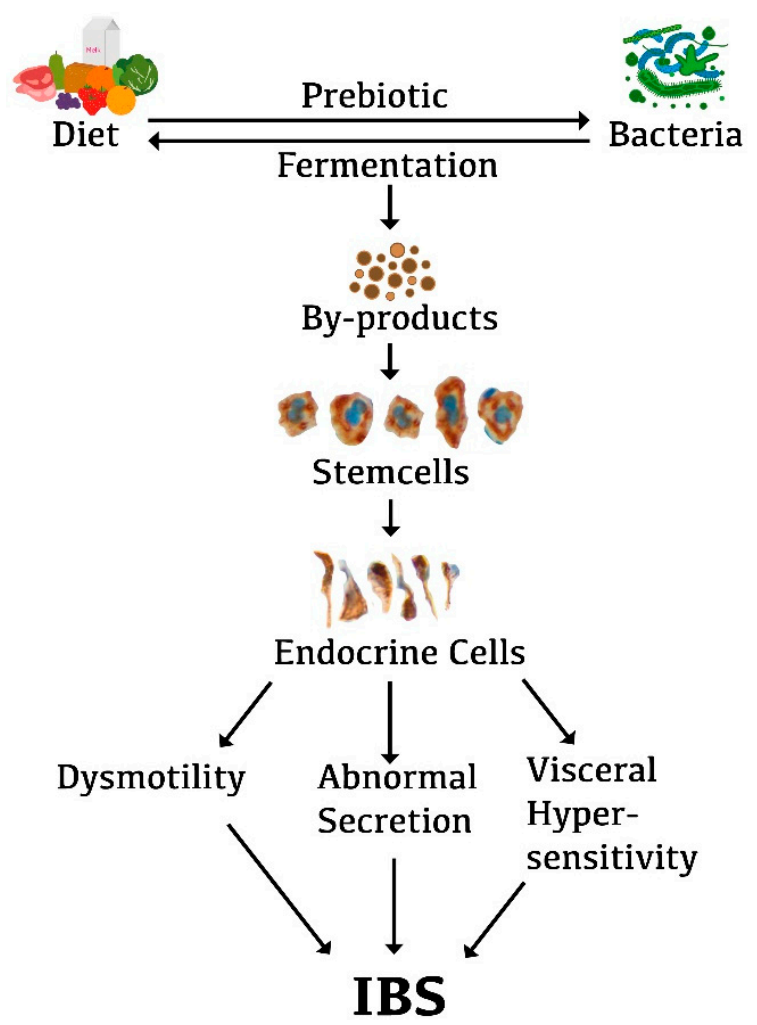

Figure 5. Schematic illustration of the possible role of the interaction of diet, gut microbiota, and gut endocrine cells in the pathophysiology of IBS. The foods we ingest act as prebiotics that favor the growth of a certain type of bacteria. These bacteria in turn ferment the diet, resulting in by-products. These by-products may act on the stem cells in a way that reduces their number. This in turn would result in a low density of gut endocrine cells. The low density of gut endocrine cells gives rise to the gut dysmotility, visceral hypersensitivity, and abnormal gut secretion that are seen in IBS patients.

The gut hormones, as mentioned previously, sense the luminal content of the gut and release their hormones accordingly. Gut luminal contents rich in proteins cause the release of certain hormones, while those rich in carbohydrates or fats cause the release of other hormones.

The composition of the diet, with different proportions of carbohydrates, proteins, and fats, is a trigger for the release of different gut hormones into the lamina propria $[40,46]$.

Diet seems to also interact with gut endocrine cells in more complicated ways. It has been shown recently that a change in diet from a common Norwegian diet to a low-FODMAP diet results in a change in the density of gastrointestinal cells towards the levels of healthy subjects [152-158]. The effect of a NICE-modified diet is not known. Furthermore, fecal microbiota transplantation (FMT) changes the density of small and large intestine endocrine cells in patients with IBS [159]. These changes in gut endocrine cells caused by a low-FODMAP diet and FMT was accompanied with an improvement in symptoms and quality of life [159].

One may speculate that diet acts as prebiotic favoring the growth of certain bacteria. These bacteria in turn ferment the diet, which results in by-products. These by-products act on gut stem cells, causing low differentiation into endocrine cells. The low density of gut endocrine cells and the subsequent low levels of certain hormones give rise to gut dysmotility, visceral hypersensitivity, and abnormal secretion (Figure 5).

\section{Conclusions}

Several endocrine cell types are scattered among the epithelial cells of the gut mucosa and secret at least 14 different hormones. These hormones regulate many functions of the gut. Some of these cells response to protein-rich luminal contents by releasing their hormones. Others response to 
carbohydrates or fat-rich luminal contents. Thus, the proportions of proteins, carbohydrates, and fats in the diet, and consequently in the gut lumen, determine which hormones are released.

The density of gut endocrine cells is lower in IBS patients than healthy subjects, probably because of a low density of stem cells and low differentiation of these cells into endocrine cells. It is believed that this abnormality plays a major role in the pathophysiology of IBS. A low FODMAP intake and FMT improve symptoms and quality of life and restore the density of the gut endocrine cells. An interaction between diet, gut microbiota, and gut endocrine cells appears to play an important role in the pathophysiology of IBS.

This interaction should be kept in mind when managing IBS patients in clinic. Patients who do not respond well to diet management should be considered as candidates for gut microbiota alteration through FMT.

Author Contributions: M.E.-S. designed the review, collected, analyzed, and interpreted the data, and drafted the manuscript, J.G.H., and T.H. contributed to the design of the review, to the analysis and interpretation of the data, and critically revised of the manuscript for important intellectual content.

Funding: The studies done by the authors and cited in this review were supported by grants from Helse Vest (grant no. 912234) and Helse Fonna (grant no. 40415).

Conflicts of Interest: The authors declare no conflict of interest.

\section{References}

1. El-Salhy, M. Recent developments in the pathophysiology of irritable bowel syndrome. World J. Gastroenterol. 2015, 21, 7621-7636. [CrossRef] [PubMed]

2. Canavan, C.; West, J.; Card, T. The epidemiology of irritable bowel syndrome. Clin. Epidemiol. 2014, 6, 71-80. [CrossRef]

3. El-Salhy, M. Irritable bowel syndrome: Diagnosis and pathogenesis. World J. Gastroenterol. 2012, 18, 5151-5163. [CrossRef] [PubMed]

4. El-Salhy, M.; Gilja, O.H.; Hatlebakk, J.G. Overlapping of irritable bowel syndrome with erosive esophagitis and the performance of Rome criteria in diagnosing IBS in a clinical setting. Mol. Med. Rep. 2019. [CrossRef] [PubMed]

5. Spiller, R.; Aziz, Q.; Creed, F.; Emmanuel, A.; Houghton, L.; Hungin, P.; Jones, R.; Kumar, D.; Rubin, G.; Trudgill, N.; et al. Guidelines on the irritable bowel syndrome: Mechanisms and practical management. Gut 2007, 56, 1770-1798. [CrossRef] [PubMed]

6. Longstreth, G.F.; Thompson, W.G.; Chey, W.D.; Houghton, L.A.; Mearin, F.; Spiller, R.C. Functional bowel disorders. Gastroenterology 2006, 130, 1480-1491. [CrossRef] [PubMed]

7. Thompson, W.G.; Irvine, E.J.; Pare, P.; Ferrazzi, S.; Rance, L. Functional gastrointestinal disorders in Canada: First population-based survey using Rome II criteria with suggestions for improving the questionnaire. Dig. Dis. Sci. 2002, 47, 225-235. [CrossRef] [PubMed]

8. Thompson, W.G.; Heaton, K.W. Functional bowel disorders in apparently healthy people. Gastroenterology 1980, 79, 283-288. [CrossRef]

9. Agreus, L.; Svardsudd, K.; Nyren, O.; Tibblin, G. Irritable bowel syndrome and dyspepsia in the general population: Overlap and lack of stability over time. Gastroenterology 1995, 109, 671-680. [CrossRef]

10. Kennedy, T.M.; Jones, R.H.; Hungin, A.P.; O'Flanagan, H.; Kelly, P. Irritable bowel syndrome, gastro-oesophageal reflux, and bronchial hyper-responsiveness in the general population. Gut 1998, 43, 770-774. [CrossRef]

11. Drossman, D.A.; Li, Z.; Andruzzi, E.; Temple, R.D.; Talley, N.J.; Thompson, W.G.; Whitehead, W.E.; Janssens, J.; Funch-Jensen, P.; Corazziari, E.; et al. U.S. householder survey of functional gastrointestinal disorders. Prevalence, sociodemography, and health impact. Dig. Dis. Sci. 1993, 38, 1569-1580. [CrossRef] [PubMed]

12. Hungin, A.P.; Whorwell, P.J.; Tack, J.; Mearin, F. The prevalence, patterns and impact of irritable bowel syndrome: An international survey of 40,000 subjects. Aliment. Pharmacol. Ther. 2003, 17, 643-650. [CrossRef] [PubMed]

13. Jones, R.; Lydeard, S. Irritable bowel syndrome in the general population. BMJ 1992, 304, 87-90. [CrossRef] 
14. O’Keefe, E.A.; Talley, N.J.; Zinsmeister, A.R.; Jacobsen, S.J. Bowel disorders impair functional status and quality of life in the elderly: A population-based study. J. Gerontol. A Biol. Sci. Med. Sci. 1995, 50, M184-M189. [CrossRef] [PubMed]

15. Everhart, J.E.; Renault, P.F. Irritable bowel syndrome in office-based practice in the United States. Gastroenterology 1991, 100, 998-1005. [CrossRef]

16. Harvey, R.F.; Salih, S.Y.; Read, A.E. Organic and Functional Disorders in 2000 Gastroenterology Outpatients. Lancet 1980, 1, 632-634. [CrossRef]

17. Quigley, E.M.; Locke, G.R.; Mueller-Lissner, S.; Paulo, L.G.; Tytgat, G.N.; Helfrich, I.; Schaefer, E. Prevalence and management of abdominal cramping and pain: A multinational survey. Aliment. Pharmacol. Ther. 2006, 24, 411-419. [CrossRef]

18. Miller, V.; Whitaker, K.; Morris, J.A.; Whorwell, P.J. Gender and irritable bowel syndrome: The male connection. J. Clin. Gastroenterol. 2004, 38, 558-560. [CrossRef]

19. El-Salhy, M.; Gundersen, D.; Hatlebakk, J.G.; Hausken, T. Irritable Bowel Syndrome: Diagnosis, Pathogenesis and Treatment Options; Nova Science Publishers Inc.: New York, NY, USA, 2012; pp. 873-878.

20. Whitehead, W.E.; Burnett, C.K.; Cook, E.W., 3rd; Taub, E. Impact of irritable bowel syndrome on quality of life. Dig. Dis. Sci. 1996, 41, 2248-2253. [CrossRef]

21. Gralnek, I.M.; Hays, R.D.; Kilbourne, A.; Naliboff, B.; Mayer, E.A. The impact of irritable bowel syndrome on health-related quality of life. Gastroenterology 2000, 119, 654-660. [CrossRef]

22. Talley, N.J.; Gabriel, S.E.; Harmsen, W.S.; Zinsmeister, A.R.; Evans, R.W. Medical costs in community subjects with irritable bowel syndrome. Gastroenterology 1995, 109, 1736-1741. [CrossRef]

23. Schuster, M.M. Defining and diagnosing irritable bowel syndrome. Am. J. Manag. Care 2001, 7, S246-S251.

24. Mitchell, C.M.; Drossman, D.A. Survey of the AGA membership relating to patients with functional gastrointestinal disorders. Gastroenterology 1987, 92, 1282-1284. [CrossRef]

25. Longstreth, G.F.; Hawkey, C.J.; Mayer, E.A.; Jones, R.H.; Naesdal, J.; Wilson, I.K.; Peacock, R.A.; Wiklund, I.K. Characteristics of patients with irritable bowel syndrome recruited from three sources: Implications for clinical trials. Aliment. Pharmacol. Ther. 2001, 15, 959-964. [CrossRef]

26. El-Salhy, M. Recent advances in the diagnosis of irritable bowel syndrome. Expert Rev. Gastroenterol. Hepatol. 2015, 9, 1161-1174. [CrossRef]

27. Drossman, D.A.; Morris, C.B.; Schneck, S.; Hu, Y.J.; Norton, N.J.; Norton, W.F.; Weinland, S.R.; Dalton, C.; Leserman, J.; Bangdiwala, S.I. International survey of patients with IBS: Symptom features and their severity, health status, treatments, and risk taking to achieve clinical benefit. J. Clin. Gastroenterol. 2009, 43, 541-550. [CrossRef]

28. Locke, G.R., 3rd; Zinsmeister, A.R.; Talley, N.J.; Fett, S.L.; Melton, L.J., 3rd. Familial association in adults with functional gastrointestinal disorders. Mayo. Clin. Proc. 2000, 75, 907-912. [CrossRef]

29. Kalantar, J.S.; Locke, G.R., 3rd; Zinsmeister, A.R.; Beighley, C.M.; Talley, N.J. Familial aggregation of irritable bowel syndrome: A prospective study. Gut 2003, 52, 1703-1707. [CrossRef]

30. Kanazawa, M.; Endo, Y.; Whitehead, W.E.; Kano, M.; Hongo, M.; Fukudo, S. Patients and nonconsulters with irritable bowel syndrome reporting a parental history of bowel problems have more impaired psychological distress. Dig. Dis. Sci. 2004, 49, 1046-1053. [CrossRef]

31. Morris-Yates, A.; Talley, N.J.; Boyce, P.M.; Nandurkar, S.; Andrews, G. Evidence of a genetic contribution to functional bowel disorder. Am. J. Gastroenterol. 1998, 93, 1311-1317. [CrossRef]

32. Levy, R.L.; Jones, K.R.; Whitehead, W.E.; Feld, S.I.; Talley, N.J.; Corey, L.A. Irritable bowel syndrome in twins: Heredity and social learning both contribute to etiology. Gastroenterology 2001, 121, 799-804. [CrossRef]

33. Lembo, A.; Zaman, M.; Jones, M.; Talley, N.J. Influence of genetics on irritable bowel syndrome, gastro-oesophageal reflux and dyspepsia: A twin study. Aliment. Pharmacol. Ther. 2007, 25, 1343-1350. [CrossRef]

34. Wojczynski, M.K.; North, K.E.; Pedersen, N.L.; Sullivan, P.F. Irritable bowel syndrome: A co-twin control analysis. Am. J. Gastroenterol. 2007, 102, 2220-2229. [CrossRef]

35. Bengtson, M.B.; Ronning, T.; Vatn, M.H.; Harris, J.R. Irritable bowel syndrome in twins: Genes and environment. Gut 2006, 55, 1754-1759. [CrossRef]

36. D'Amato, M. Genes and functional GI disorders: From casual to causal relationship. Neurogastroenterol. Motil. 2013, 25, 638-649. [CrossRef] 
37. El-Salhy, M.; Ostgaard, H.; Gundersen, D.; Hatlebakk, J.G.; Hausken, T. The role of diet in the pathogenesis and management of irritable bowel syndrome (Review). Int. J. Mol. Med. 2012, 29, 723-731. [CrossRef]

38. Ostgaard, H.; Hausken, T.; Gundersen, D.; El-Salhy, M. Diet and effects of diet management on quality of life and symptoms in patients with irritable bowel syndrome. Mol. Med. Rep. 2012, 5, 1382-1390. [CrossRef]

39. El-Salhy, M.; Gilja, O.H.; Gundersen, D.; Hatlebakk, J.G.; Hausken, T. Interaction between ingested nutrients and gut endocrine cells in patients with irritable bowel syndrome (Review). Int. J. Mol. Med. 2014, 34, 363-371. [CrossRef]

40. El-Salhy, M.; Mazzawi, T.; Hausken, T.; Hatlebakk, J.G. Interaction between diet and gastrointestinal endocrine cells. Biomed. Rep. 2016, 4, 651-656. [CrossRef]

41. El-Salhy, M.; Lilbo, E.; Reinemo, A.; Salmeøid, L.; Hausken, T. Effects of a health program comprising reassurance, diet management, probiotic administration and regular exercise on symptoms and quality of life in patients with irritable bowel syndrome. Gastroenterol. Insights 2010, 2, 21-26. [CrossRef]

42. Jarrett, M.; Heitkemper, M.M.; Bond, E.F.; Georges, J. Comparison of diet composition in women with and without functional bowel disorder. Gastroenterol. Nurs. 1994, 16, 253-258. [CrossRef]

43. Saito, Y.A.; Locke, G.R., 3rd; Weaver, A.L.; Zinsmeister, A.R.; Talley, N.J. Diet and functional gastrointestinal disorders: A population-based case-control study. Am. J. Gastroenterol. 2005, 100, 2743-2748. [CrossRef]

44. El-Salhy, M.; Gundersen, D. Diet in irritable bowel syndrome. Nutr. J. 2015, 14, 36. [CrossRef]

45. El-Salhy, M.; Hatlebakk, J.G.; Gilja, O.H.; Hausken, T. The relation between celiac disease, nonceliac gluten sensitivity and irritable bowel syndrome. Nutr. J. 2015, 14, 92. [CrossRef]

46. El-Salhy, M.; Gundersen, D.; Hatlebakk, J.G.; Hausken, T. Diet and irritable bowel syndrome, with a focus on appetite-regulating hormones. In Nutrition in the Prevention and Treatment of Abdominal Obesity; Watson, R.R., Ed.; Elsevier: San Diego, CA, USA, 2014; pp. 5-16.

47. El-Salhy, M. Diet in the pathophysiology and management of irritable bowel syndrome. Clevel. Clin. J. Med. 2016, 83, 663-664. [CrossRef]

48. Staudacher, H.M.; Whelan, K.; Irving, P.M.; Lomer, M.C. Comparison of symptom response following advice for a diet low in fermentable carbohydrates (FODMAPs) versus standard dietary advice in patients with irritable bowel syndrome. J. Hum. Nutr. Diet. 2011, 24, 487-495. [CrossRef]

49. Eswaran, S.L.; Chey, W.D.; Han-Markey, T.; Ball, S.; Jackson, K. A Randomized Controlled Trial Comparing the Low FODMAP Diet vs. Modified NICE Guidelines in US Adults with IBS-D. Am. J. Gastroenterol. 2016, 111, 1824-1832. [CrossRef]

50. Bohn, L.; Storsrud, S.; Liljebo, T.; Collin, L.; Lindfors, P.; Tornblom, H.; Simren, M. Diet low in FODMAPs reduces symptoms of irritable bowel syndrome as well as traditional dietary advice: A randomized controlled trial. Gastroenterology 2015, 149, 1399-1407.e2. [CrossRef]

51. Halmos, E.P.; Christophersen, C.T.; Bird, A.R.; Shepherd, S.J.; Gibson, P.R.; Muir, J.G. Diets that differ in their FODMAP content alter the colonic luminal microenvironment. Gut 2015, 64, 93-100. [CrossRef]

52. Catassi, G.; Lionetti, E.; Gatti, S.; Catassi, C. The Low FODMAP Diet: Many Question Marks for a Catchy Acronym. Nutrients 2017, 9, 292. [CrossRef]

53. Staudacher, H.M.; Whelan, K. The low FODMAP diet: Recent advances in understanding its mechanisms and efficacy in IBS. Gut 2017, 66, 1517-1527. [CrossRef]

54. McKenzie, Y.A.; Alder, A.; Anderson, W.; Wills, A.; Goddard, L.; Gulia, P.; Jankovich, E.; Mutch, P.; Reeves, L.B.; Singer, A.; et al. British Dietetic Association evidence-based guidelines for the dietary management of irritable bowel syndrome in adults. J. Hum. Nutr. Diet. 2012, 25, 260-274. [CrossRef]

55. McKenzie, Y.A.; Thompson, J.; Gulia, P.; Lomer, M.C. British Dietetic Association systematic review of systematic reviews and evidence-based practice guidelines for the use of probiotics in the management of irritable bowel syndrome in adults (2016 update). J. Hum. Nutr. Diet. 2016, 29, 576-592. [CrossRef]

56. Simren, M.; Mansson, A.; Langkilde, A.M.; Svedlund, J.; Abrahamsson, H.; Bengtsson, U.; Bjornsson, E.S. Food-related gastrointestinal symptoms in the irritable bowel syndrome. Digestion 2001, 63, 108-115. [CrossRef]

57. Monsbakken, K.W.; Vandvik, P.O.; Farup, P.G. Perceived food intolerance in subjects with irritable bowel syndrome-Etiology, prevalence and consequences. Eur. J. Clin. Nutr. 2006, 60, 667-672. [CrossRef]

58. Bohn, L.; Storsrud, S.; Simren, M. Nutrient intake in patients with irritable bowel syndrome compared with the general population. Neurogastroenterol. Motil. 2013, 25, 23e1. [CrossRef] 
59. Bagyanszki, M.; Bodi, N. Gut region-dependent alterations of nitrergic myenteric neurons after chronic alcohol consumption. World J. Gastrointest. Pathophysiol. 2015, 6, 51-57. [CrossRef]

60. Bagyanszki, M.; Krecsmarik, M.; De Winter, B.Y.; De Man, J.G.; Fekete, E.; Pelckmans, P.A.; Adriaensen, D.; Kroese, A.B.; Van Nassauw, L.; Timmermans, J.P. Chronic alcohol consumption affects gastrointestinal motility and reduces the proportion of neuronal NOS-immunoreactive myenteric neurons in the murine jejunum. Anat. Rec. 2010, 293, 1536-1542. [CrossRef]

61. Bagyanszki, M.; Torfs, P.; Krecsmarik, M.; Fekete, E.; Adriaensen, D.; Van Nassauw, L.; Timmermans, J.P.; Kroese, A.B. Chronic alcohol consumption induces an overproduction of NO by nNOS- and iNOS-expressing myenteric neurons in the murine small intestine. Neurogastroenterol. Motil. 2011, 23, e237-e248. [CrossRef]

62. Bodi, N.; Jancso, Z.; Talapka, P.; Pal, A.; Poles, M.Z.; Bagyanszki, M.; Hermesz, E.; Fekete, E. Gut region-specific rearrangement of the cellular and subcellular compartments of nitric oxide synthase isoforms after chronic ethanol consumption in rats. Histol. Histopathol. 2014, 29, 1547-1555.

63. Krecsmarik, M.; Izbeki, F.; Bagyanszki, M.; Linke, N.; Bodi, N.; Kaszaki, J.; Katarova, Z.; Szabo, A.; Fekete, E.; Wittmann, T. Chronic ethanol exposure impairs neuronal nitric oxide synthase in the rat intestine. Alcohol Clin. Exp. Res. 2006, 30, 967-973. [CrossRef]

64. Nazer, H.; Wright, R.A. The effect of alcohol on the human alimentary tract: A review. J. Clin. Gastroenterol. 1983, 5, 361-365.

65. Hayes, P.; Corish, C.; O’Mahony, E.; Quigley, E.M. A dietary survey of patients with irritable bowel syndrome. J. Hum. Nutr. Diet. 2014, 27 (Suppl. S2), 36-47. [CrossRef]

66. Bohn, L.; Storsrud, S.; Tornblom, H.; Bengtsson, U.; Simren, M. Self-reported food-related gastrointestinal symptoms in IBS are common and associated with more severe symptoms and reduced quality of life. Am. J. Gastroenterol. 2013, 108, 634-641. [CrossRef]

67. Faresjo, A.; Johansson, S.; Faresjo, T.; Roos, S.; Hallert, C. Sex differences in dietary coping with gastrointestinal symptoms. Eur. J. Gastroenterol. Hepatol. 2010, 22, 327-333. [CrossRef]

68. Reding, K.W.; Cain, K.C.; Jarrett, M.E.; Eugenio, M.D.; Heitkemper, M.M. Relationship between patterns of alcohol consumption and gastrointestinal symptoms among patients with irritable bowel syndrome. Am. J. Gastroenterol. 2013, 108, 270-276. [CrossRef]

69. McKenzie, Y.A.; Bowyer, R.K.; Leach, H.; Gulia, P.; Horobin, J.; O’Sullivan, N.A.; Pettitt, C.; Reeves, L.B.; Seamark, L.; Williams, M.; et al. British Dietetic Association systematic review and evidence-based practice guidelines for the dietary management of irritable bowel syndrome in adults (2016 update). J. Hum. Nutr. Diet. 2016, 29, 549-575. [CrossRef]

70. Gonlachanvit, S.; Mahayosnond, A.; Kullavanijaya, P. Effects of chili on postprandial gastrointestinal symptoms in diarrhoea predominant irritable bowel syndrome: Evidence for capsaicin-sensitive visceral nociception hypersensitivity. Neurogastroenterol. Motil. 2009, 21, 23-32. [CrossRef]

71. Schmulson, M.J.; Valdovinos, M.A.; Milke, P. Chili pepper and rectal hyperalgesia in irritable bowel syndrome. Am. J. Gastroenterol. 2003, 98, 1214-1215. [CrossRef]

72. Aniwan, S.; Gonlachanvit, S. Effects of Chili Treatment on Gastrointestinal and Rectal Sensation in Diarrhea-predominant Irritable Bowel Syndrome: A Randomized, Double-blinded, Crossover Study. J. Neurogastroenterol. Motil. 2014, 20, 400-406. [CrossRef]

73. Bortolotti, M.; Porta, S. Effect of red pepper on symptoms of irritable bowel syndrome: Preliminary study. Dig. Dis. Sci. 2011, 56, 3288-3295. [CrossRef]

74. Patcharatrakul, T.; Gonlachanvit, S. Chili Peppers, Curcumins, and Prebiotics in Gastrointestinal Health and Disease. Curr. Gastroenterol. Rep. 2016, 18, 19. [CrossRef]

75. Ferrucci, L.M.; Daniel, C.R.; Kapur, K.; Chadha, P.; Shetty, H.; Graubard, B.I.; George, P.S.; Osborne, W.; Yurgalevitch, S.; Devasenapathy, N.; et al. Measurement of spices and seasonings in India: opportunities for cancer epidemiology and prevention. Asian Pac. J. Cancer Prev. APJCP 2010, 11, 1621-1629.

76. Govindarajan, V.S.; Rajalakshmi, D.; Chand, N. Capsicum-Production, technology, chemistry, and quality. Part IV. Evaluation of quality. Crit. Rev. Food Sci. Nutr. 1987, 25, 185-282. [CrossRef]

77. Govindarajan, V.S.; Sathyanarayana, M.N. Capsicum-Production, technology, chemistry, and quality. Part V. Impact on physiology, pharmacology, nutrition, and metabolism; structure, pungency, pain, and desensitization sequences. Crit. Rev. Food Sci. Nutr. 1991, 29, 435-474. [CrossRef]

78. Ghoshal, U.C.; Shukla, R.; Ghoshal, U.; Gwee, K.A.; Ng, S.C.; Quigley, E.M. The gut microbiota and irritable bowel syndrome: Friend or foe? Int. J. Inflam. 2012, 2012, 151085. [CrossRef] 
79. Gwee, K.A. Irritable bowel syndrome in developing countries-A disorder of civilization or colonization? Neurogastroenterol. Motil. 2005, 17, 317-324. [CrossRef]

80. Gwee, K.A.; Lu, C.L.; Ghoshal, U.C. Epidemiology of irritable bowel syndrome in Asia: Something old, something new, something borrowed. J. Gastroenterol. Hepatol. 2009, 24, 1601-1607. [CrossRef]

81. Ghoshal, U.C.; Abraham, P.; Bhatt, C.; Choudhuri, G.; Bhatia, S.J.; Shenoy, K.T.; Banka, N.H.; Bose, K.; Bohidar, N.P.; Chakravartty, K.; et al. Epidemiological and clinical profile of irritable bowel syndrome in India: Report of the Indian Society of Gastroenterology Task Force. Indian J. Gastroenterol. 2008, 27, 22-28.

82. Thursby, E.; Juge, N. Introduction to the human gut microbiota. Biochem. J. 2017, 474, 1823-1836. [CrossRef]

83. Hugon, P.; Dufour, J.C.; Colson, P.; Fournier, P.E.; Sallah, K.; Raoult, D. A comprehensive repertoire of prokaryotic species identified in human beings. Lancet Infects Dis. 2015, 15, 1211-1219. [CrossRef]

84. Ley, R.E.; Hamady, M.; Lozupone, C.; Turnbaugh, P.J.; Ramey, R.R.; Bircher, J.S.; Schlegel, M.L.; Tucker, T.A.; Schrenzel, M.D.; Knight, R.; et al. Evolution of mammals and their gut microbes. Science 2008, 320, 1647-1651. [CrossRef]

85. Kriss, M.; Hazleton, K.Z.; Nusbacher, N.M.; Martin, C.G.; Lozupone, C.A. Low diversity gut microbiota dysbiosis: Drivers, functional implications and recovery. Curr. Opin. Microbiol. 2018, 44, 34-40. [CrossRef]

86. Wilson, B.C.; Vatanen, T.; Cutfield, W.S.; O'Sullivan, J.M. The Super-Donor Phenomenon in Fecal Microbiota Transplantation. Front. Cell Infect. Microbiol. 2019, 9, 2. [CrossRef]

87. Maier, L.; Pruteanu, M.; Kuhn, M.; Zeller, G.; Telzerow, A.; Anderson, E.E.; Brochado, A.R.; Fernandez, K.C.; Dose, H.; Mori, H.; et al. Extensive impact of non-antibiotic drugs on human gut bacteria. Nature 2018, 555, 623-628. [CrossRef]

88. El-Salhy, M.; Mazzawi, T. Fecal microbiota transplantation for managing irritable bowel syndrome. Expert Rev. Gastroenterol. Hepatol. 2018, 12, 439-445. [CrossRef]

89. Casen, C.; Vebo, H.C.; Sekelja, M.; Hegge, F.T.; Karlsson, M.K.; Ciemniejewska, E.; Dzankovic, S.; Froyland, C.; Nestestog, R.; Engstrand, L.; et al. Deviations in human gut microbiota: A novel diagnostic test for determining dysbiosis in patients with IBS or IBD. Aliment. Pharmacol. Ther. 2015, 42, 71-83. [CrossRef]

90. Enck, P.; Mazurak, N. Dysbiosis in Functional Bowel Disorders. Ann. Nutr. Metab. 2018, 72, $296-306$. [CrossRef]

91. Pozuelo, M.; Panda, S.; Santiago, A.; Mendez, S.; Accarino, A.; Santos, J.; Guarner, F.; Azpiroz, F.; Manichanh, C. Reduction of butyrate- and methane-producing microorganisms in patients with Irritable Bowel Syndrome. Sci. Rep. 2015, 5, 12693. [CrossRef]

92. Chong, P.P.; Chin, V.K.; Looi, C.Y.; Wong, W.F.; Madhavan, P.; Yong, V.C. The Microbiome and Irritable Bowel Syndrome-A Review on the Pathophysiology, Current Research and Future Therapy. Front. Microbiol. 2019, 10, 1136. [CrossRef]

93. Collins, S.M. A role for the gut microbiota in IBS. Nat. Rev. Gastroenterol. Hepatol. 2014, 11, 497-505. [CrossRef]

94. El-Salhy, M.; Seim, I.; Chopin, L.; Gundersen, D.; Hatlebakk, J.G.; Hausken, T. Irritable bowel syndrome: The role of gut neuroendocrine peptides. Front. Biosci. 2012, 4, 2783-2800. [CrossRef]

95. Mawe, G.M.; Coates, M.D.; Moses, P.L. Review article: Intestinal serotonin signalling in irritable bowel syndrome. Aliment. Pharmacol. Ther. 2006, 23, 1067-1076. [CrossRef]

96. Wade, P.R.; Chen, J.; Jaffe, B.; Kassem, I.S.; Blakely, R.D.; Gershon, M.D. Localization and function of a 5-HT transporter in crypt epithelia of the gastrointestinal tract. J. Neurosci. 1996, 16, 2352-2364. [CrossRef]

97. Gershon, M.D.; Tack, J. The serotonin signaling system: From basic understanding to drug development for functional GI disorders. Gastroenterology 2007, 132, 397-414. [CrossRef]

98. Gershon, M.D. 5-Hydroxytryptamine (serotonin) in the gastrointestinal tract. Curr. Opin. Endocrinol. Diabetes Obes. 2013, 20, 14-21. [CrossRef]

99. Gershon, M.D. Serotonin is a sword and a shield of the bowel: Serotonin plays offense and defense. Trans. Am. Clin. Climatol. Assoc. 2012, 123, 268-280, discussion 280.

100. El-Salhy, M.; Mazzawi, T.; Gundersen, D.; Hatlebakk, J.G.; Hausken, T. The role of peptide YY in gastrointestinal diseases and disorders (Review). Int. J. Mol. Med. 2013, 31, 275-282. [CrossRef]

101. Dubrasquet, M.; Bataille, D.; Gespach, C. Oxyntomodulin (glucagon-37 or bioactive enteroglucagon): A potent inhibitor of pentagastrin-stimulated acid secretion in rats. Biosci. Rep. 1982, 2, 391-395. [CrossRef] 
102. Schjoldager, B.T.; Baldissera, F.G.; Mortensen, P.E.; Holst, J.J.; Christiansen, J. Oxyntomodulin: A potential hormone from the distal gut. Pharmacokinetics and effects on gastric acid and insulin secretion in man. Eur. J. Clin. Investig. 1988, 18, 499-503. [CrossRef]

103. Schjoldager, B.; Mortensen, P.E.; Myhre, J.; Christiansen, J.; Holst, J.J. Oxyntomodulin from distal gut. Role in regulation of gastric and pancreatic functions. Dig. Dis. Sci. 1989, 34, 1411-1419. [CrossRef]

104. Dakin, C.L.; Small, C.J.; Batterham, R.L.; Neary, N.M.; Cohen, M.A.; Patterson, M.; Ghatei, M.A.; Bloom, S.R. Peripheral oxyntomodulin reduces food intake and body weight gain in rats. Endocrinology 2004, 145, 2687-2695. [CrossRef]

105. Wynne, K.; Park, A.J.; Small, C.J.; Patterson, M.; Ellis, S.M.; Murphy, K.G.; Wren, A.M.; Frost, G.S.; Meeran, K.; Ghatei, M.A.; et al. Subcutaneous oxyntomodulin reduces body weight in overweight and obese subjects: A double-blind, randomized, controlled trial. Diabetes 2005, 54, 2390-2395. [CrossRef]

106. Camilleri, M. Peripheral mechanisms in irritable bowel syndrome. N. Engl. J. Med. 2012, 367, $1626-1635$. [CrossRef]

107. Jianu, C.S.; Fossmark, R.; Syversen, U.; Hauso, O.; Waldum, H.L. A meal test improves the specificity of chromogranin A as a marker of neuroendocrine neoplasia. Tumour Biol. 2010, 31, 373-380. [CrossRef]

108. Gunawardene, A.R.; Corfe, B.M.; Staton, C.A. Classification and functions of enteroendocrine cells of the lower gastrointestinal tract. Int. J. Exp. Pathol. 2011, 92, 219-231. [CrossRef]

109. May, C.L.; Kaestner, K.H. Gut endocrine cell development. Mol. Cell Endocrinol. 2010, 323, 70-75. [CrossRef]

110. Sandstrom, O.; El-Salhy, M. Ageing and endocrine cells of human duodenum. Mech. Ageing Dev. 1999, 108, 39-48. [CrossRef]

111. El-Salhy, M. Ghrelin in gastrointestinal diseases and disorders: A possible role in the pathophysiology and clinical implications (review). Int. J. Mol. Med. 2009, 24, 727-732. [CrossRef]

112. Tolhurst, G.; Reimann, F.; Gribble, F.M. Intestinal sensing of nutrients. Handb. Exp. Pharmacol. 2012, 309-335. [CrossRef]

113. Lee, J.; Cummings, B.P.; Martin, E.; Sharp, J.W.; Graham, J.L.; Stanhope, K.L.; Havel, P.J.; Raybould, H.E. Glucose sensing by gut endocrine cells and activation of the vagal afferent pathway is impaired in a rodent model of type 2 diabetes mellitus. Am. J. Physiol. Regul. Integr. Comp. Physiol. 2012, 302, R657-R666. [CrossRef]

114. Parker, H.E.; Reimann, F.; Gribble, F.M. Molecular mechanisms underlying nutrient-stimulated incretin secretion. Expert Rev. Mol. Med. 2010, 12, e1. [CrossRef]

115. Raybould, H.E. Nutrient sensing in the gastrointestinal tract: Possible role for nutrient transporters. J. Physiol. Biochem. 2008, 64, 349-356. [CrossRef]

116. San Gabriel, A.; Nakamura, E.; Uneyama, H.; Torii, K. Taste, visceral information and exocrine reflexes with glutamate through umami receptors. J. Med. Investig. 2009, 56, 209-217. [CrossRef]

117. Rudholm, T.; Wallin, B.; Theodorsson, E.; Naslund, E.; Hellstrom, P.M. Release of regulatory gut peptides somatostatin, neurotensin and vasoactive intestinal peptide by acid and hyperosmolal solutions in the intestine in conscious rats. Regul. Pept. 2009, 152, 8-12. [CrossRef]

118. Sternini, C.; Anselmi, L.; Rozengurt, E. Enteroendocrine cells: A site of "taste" in gastrointestinal chemosensing. Curr. Opin. Endocrinol. Diabetes Obes. 2008, 15, 73-78. [CrossRef]

119. Sternini, C. Taste receptors in the gastrointestinal tract. IV. Functional implications of bitter taste receptors in gastrointestinal chemosensing. Am. J. Physiol. Gastrointest. Liver Physiol. 2007, 292, G457-G461. [CrossRef]

120. Buchan, A.M. Nutrient Tasting and Signaling Mechanisms in the Gut III. Endocrine cell recognition of luminal nutrients. Am. J. Physiol. 1999, 277, G1103-G1107.

121. Montero-Hadjadje, M.; Elias, S.; Chevalier, L.; Benard, M.; Tanguy, Y.; Turquier, V.; Galas, L.; Yon, L.; Malagon, M.M.; Driouich, A.; et al. Chromogranin A promotes peptide hormone sorting to mobile granules in constitutively and regulated secreting cells: Role of conserved N- and C-terminal peptides. J. Biol. Chem. 2009, 284, 12420-12431. [CrossRef]

122. Shooshtarizadeh, P.; Zhang, D.; Chich, J.F.; Gasnier, C.; Schneider, F.; Haikel, Y.; Aunis, D.; Metz-Boutigue, M.H. The antimicrobial peptides derived from chromogranin/secretogranin family, new actors of innate immunity. Regul. Pept. 2010, 165, 102-110. [CrossRef]

123. Rindi, G.; Inzani, F.; Solcia, E. Pathology of gastrointestinal disorders. Endocrinol. Metab. Clin. N. Am. 2010, 39, 713-727. [CrossRef] 
124. Seim, I.; El-Salhy, M.; Hausken, T.; Gundersen, D.; Chopin, L. Ghrelin and the brain-gut axis as a pharmacological target for appetite control. Curr. Pharm. Des. 2012, 18, 768-775. [CrossRef]

125. Dizdar, V.; Spiller, R.; Singh, G.; Hanevik, K.; Gilja, O.H.; El-Salhy, M.; Hausken, T. Relative importance of abnormalities of CCK and 5-HT (serotonin) in Giardia-induced post-infectious irritable bowel syndrome and functional dyspepsia. Aliment. Pharmacol. Ther. 2010, 31, 883-891. [CrossRef]

126. El-Salhy, M.; Gilja, O.H. Abnormalities in ileal stem, neurogenin 3, and enteroendocrine cells in patients with irritable bowel syndrome. BMC Gastroenterol. 2017, 17, 90. [CrossRef]

127. El-Salhy, M.; Gilja, O.H.; Gundersen, D.; Hatlebakk, J.G.; Hausken, T. Duodenal chromogranin a cell density as a biomarker for the diagnosis of irritable bowel syndrome. Gastroenterol. Res. Pract. 2014, 2014, 462856. [CrossRef]

128. El-Salhy, M.; Gilja, O.H.; Gundersen, D.; Hatlebakk, J.G.; Hausken, T. Endocrine cells in the ileum of patients with irritable bowel syndrome. World J. Gastroenterol. 2014, 20, 2383-2391. [CrossRef]

129. El-Salhy, M.; Gilja, O.H.; Gundersen, D.; Hausken, T. Endocrine cells in the oxyntic mucosa of the stomach in patients with irritable bowel syndrome. World J. Gastrointest. Endosc. 2014, 6, 176-185. [CrossRef]

130. El-Salhy, M.; Gilja, O.H.; Hatlebakk, J.G.; Hausken, T. Stomach antral endocrine cells in patients with irritable bowel syndrome. Int. J. Mol. Med. 2014, 34, 967-974. [CrossRef]

131. El-Salhy, M.; Gilja, O.H.; Hausken, T. Chromogranin A cells in the stomachs of patients with sporadic irritable bowel syndrome. Mol. Med. Rep. 2014, 10, 1753-1757. [CrossRef]

132. El-Salhy, M.; Gundersen, D.; Hatlebakk, J.G.; Gilja, O.H.; Hausken, T. Abnormal rectal endocrine cells in patients with irritable bowel syndrome. Regul. Pept. 2014, 188, 60-65. [CrossRef]

133. El-Salhy, M.; Hatlebakk, J.G.; Gilja, O.H.; Hausken, T. Densities of rectal peptide YY and somatostatin cells as biomarkers for the diagnosis of irritable bowel syndrome. Peptides 2015, 67, 12-19. [CrossRef]

134. El-Salhy, M.; Patcharatrakul, T.; Hatlebakk, J.G.; Hausken, T.; Gilja, O.H.; Gonlachanvit, S. Chromogranin A cell density in the large intestine of Asian and European patients with irritable bowel syndrome. Scand. J. Gastroenterol. 2017, 52, 691-697. [CrossRef]

135. El-Salhy, M.; Patcharatrakul, T.; Hatlebakk, J.G.; Hausken, T.; Gilja, O.H.; Gonlachanvit, S. Enteroendocrine, Musashi 1 and neurogenin 3 cells in the large intestine of Thai and Norwegian patients with irritable bowel syndrome. Scand. J. Gastroenterol. 2017, 52, 1331-1339. [CrossRef]

136. El-Salhy, M.; Vaali, K.; Dizdar, V.; Hausken, T. Abnormal small-intestinal endocrine cells in patients with irritable bowel syndrome. Dig. Dis. Sci. 2010, 55, 3508-3513. [CrossRef]

137. Wang, J.; Cortina, G.; Wu, S.V.; Tran, R.; Cho, J.H.; Tsai, M.J.; Bailey, T.J.; Jamrich, M.; Ament, M.E.; Treem, W.R.; et al. Mutant neurogenin-3 in congenital malabsorptive diarrhea. N. Engl. J. Med. 2006, 355, 270-280. [CrossRef]

138. Fishbein, T.M.; Novitskiy, G.; Lough, D.M.; Matsumoto, C.; Kaufman, S.S.; Shetty, K.; Zasloff, M. Rejection reversibly alters enteroendocrine cell renewal in the transplanted small intestine. Am. J. Transplant. 2009, 9, 1620-1628. [CrossRef]

139. Jenny, M.; Uhl, C.; Roche, C.; Duluc, I.; Guillermin, V.; Guillemot, F.; Jensen, J.; Kedinger, M.; Gradwohl, G. Neurogenin 3 is differentially required for endocrine cell fate specification in the intestinal and gastric epithelium. EMBO J. 2002, 21, 6338-6347. [CrossRef]

140. Montgomery, R.K.; Breault, D.T. Small intestinal stem cell markers. J. Anat. 2008, 213, 52-58. [CrossRef]

141. Potten, C.S.; Booth, C.; Tudor, G.L.; Booth, D.; Brady, G.; Hurley, P.; Ashton, G.; Clarke, R.; Sakakibara, S.; Okano, H. Identification of a putative intestinal stem cell and early lineage marker; musashi-1. Differentiation 2003, 71, 28-41. [CrossRef]

142. Kayahara, T.; Sawada, M.; Takaishi, S.; Fukui, H.; Seno, H.; Fukuzawa, H.; Suzuki, K.; Hiai, H.; Kageyama, R.; Okano, H.; et al. Candidate markers for stem and early progenitor cells, Musashi-1 and Hes1, are expressed in crypt base columnar cells of mouse small intestine. FEBS Lett. 2003, 535, 131-135. [CrossRef]

143. He, X.C.; Yin, T.; Grindley, J.C.; Tian, Q.; Sato, T.; Tao, W.A.; Dirisina, R.; Porter-Westpfahl, K.S.; Hembree, M.; Johnson, T.; et al. PTEN-deficient intestinal stem cells initiate intestinal polyposis. Nat. Genet. 2007, 39, 189-198. [CrossRef]

144. Schonhoff, S.E.; Giel-Moloney, M.; Leiter, A.B. Minireview: Development and differentiation of gut endocrine cells. Endocrinology 2004, 145, 2639-2644. [CrossRef]

145. Schonhoff, S.E.; Giel-Moloney, M.; Leiter, A.B. Neurogenin 3-expressing progenitor cells in the gastrointestinal tract differentiate into both endocrine and non-endocrine cell types. Dev. Biol. 2004, 270, 443-454. [CrossRef] 
146. El-Salhy, M.; Hatlebakk, J.G.; Hausken, T. The reduction in duodenal endocrine cells in IBSis associated with stem cell abnormalities. World. J. Gastroenterol. 2015, 21, 9577-9587. [CrossRef]

147. El-Salhy, M.; Hatlebakk, J.G.; Gilja, O.H.; Hausken, T. Irritable bowel syndrome: Recent developments in diagnosis, pathophysiology, and treatment. Expert Rev. Gastroenterol. Hepatol. 2014, 8, 435-443. [CrossRef]

148. El-Salhy, M.; Gundersen, D.; Gilja, O.H.; Hatlebakk, J.G.; Hausken, T. Is irritable bowel syndrome an organic disorder? World J. Gastroenterol. 2014, 20, 384-400. [CrossRef]

149. El-Salhy, M.; Hausken, T.; Gilja, O.H.; Hatlebakk, J.G. The possible role of gastrointestinal endocrine cells in the pathophysiology of irritable bowel syndrome. Expert Rev. Gastroenterol. Hepatol. 2017, 11, 139-148. [CrossRef]

150. Hill, P.; Muir, J.G.; Gibson, P.R. Controversies and Recent Developments of the Low-FODMAP Diet. Gastroenterol. Hepatol. 2017, 13, 36-45.

151. Biesiekierski, J.R.; Jalanka, J.; Staudacher, H.M. Can Gut Microbiota Composition Predict Response to Dietary Treatments? Nutrients 2019, 11, 1134. [CrossRef]

152. Mazzawi, T.; El-Salhy, M. Changes in small intestinal chromogranin A-immunoreactive cell densities in patients with irritable bowel syndrome after receiving dietary guidance. Int. J. Mol. Med. 2016, 37, 1247-1253. [CrossRef]

153. Mazzawi, T.; El-Salhy, M. Dietary guidance and ileal enteroendocrine cells in patients with irritable bowel syndrome. Exp. Ther. Med. 2016, 12, 1398-1404. [CrossRef]

154. Mazzawi, T.; Gundersen, D.; Hausken, T.; El-Salhy, M. Increased gastric chromogranin A cell density following changes to diets of patients with irritable bowel syndrome. Mol. Med. Rep. 2014, 10, 2322-2326. [CrossRef]

155. Mazzawi, T.; Gundersen, D.; Hausken, T.; El-Salhy, M. Increased chromogranin A cell density in the large intestine of patients with irritable bowel syndrome after receiving dietary guidance. Mol. Med. Rep. 2015, in press. [CrossRef]

156. Mazzawi, T.; Hausken, T.; Gundersen, D.; El-Salhy, M. Effects of dietary guidance on the symptoms, quality of life and habitual dietary intake of patients with irritable bowel syndrome. Mol. Med. Rep. 2013, 8, 845-852. [CrossRef]

157. Mazzawi, T.; Hausken, T.; Gundersen, D.; El-Salhy, M. Effect of dietary management on the gastric endocrine cells in patients with irritable bowel syndrome. Eur. J. Clin. Nutr. 2014. [CrossRef]

158. Mazzawi, T.; Hausken, T.; Gundersen, D.; El-Salhy, M. Dietary guidance normalizes large intestinal endocrine cell densities in patients with irritable bowel syndrome. Eur. J. Clin. Nutr. 2016, 70, 175-181. [CrossRef]

159. Mazzawi, T.; Lied, G.A.; El-Sahy, M.; Gilja, O.H.; Hatlebakk, J.G.; Hausken, T. Effect of fecal microbiota transplantation on the symptoms and duodenal enteroendocrine cells in patients with irritable bowel syndrome. United Eur. Gastroenterol. J. 2016, 4 (Suppl. 5), 677. 